\title{
NOTE
}

\section{STATE RESPONSE TO THE EDUCATION FOR ALL HANDICAPPED CHILDREN ACT OF 1975}

I

\section{INTRODUCTION}

Efforts to establish a strong federal policy for educating handicapped children in the United States culminated in 1975 in the Education for All Handicapped Children Act (hereinafter "EAHCA" or the "Act"). ${ }^{1}$ This Act, which is designed to supplement existing state programs for the delivery of special education services, offers fiscal incentives to states which choose to meet the standards of the EAHCA. The Act requires participating states to establish policies and to submit plans which assure all handicapped children the right to a "free appropriate public education." Consistent with Congress' belief that the participation of concerned parties, combined with the use of due process guarantees, would best ensure the provision of educational services appropriate to the needs of the individual child, the requirements of the Act are more procedural than substantive. ${ }^{2}$

The Act is designed to leave many of the policymaking and substantive decisions with state and local educational agencies. This design is consistent with the nation's traditional policy of decentralizing the responsibility for education to the greatest extent practicable. This approach also allows states to experiment and innovate in devising ways to deliver a free appropriate education to handicapped children.

This note was conceived with the purpose of surveying state responses to the EAHCA to determine whether the federal act has produced the intended experimentation. The authors looked in particular for variation among the states in several substantive areas, as well as in certain funding policies. The survey also looked at whether the states have obligated themselves to provide services above and beyond those required by the EAHCA. This survey was intended to be restricted to an examination of state statutory and decisional law and of state educational agency decisions rendered thereunder. Limiting the scope of the survey in this manner turned out to be much more difficult than contemplated since the vast majority of claims relating to special educa-

Copyright $(1985$ by Law and Contemporary Problems

1. 20 U.S.C. $\$ \S 1400-1461$ (1982). For a summary of the Act, see Lora v. Board of Educ., $456 \mathrm{~F}$. Supp. 1211 (E.D.N.Y. 1978), vacated, 623 F.2d 248 (2d Cir. 1980).

2. See S. Rep. No. 168, 94th Cong., 1st Sess. 11-12, reprinted in 1975 U.S. Code Cong. \& Ad. News 1425, 1435-36. 
tion have been brought and decided under the federal act. Many decisions, while recognizing the existence of applicable state law, virtually ignore the state law as grounds for decision because of (1) its substantial similarity to the federal mandate and (2) the decisionmaker's recognition that the federal act supersedes any conflicting state law. Consequently, in a few areas the authors have had to refer to cases decided solely under the EAHCA.

The findings herein indicate a high degree of uniformity among the states in most substantive areas, such as the provision of transportation and other related services, homebound and year-round services, and reimbursements for unilateral placements. With respect to the range of each state's coverage, some variations are found in eligibility ages and in the length of time services will be provided. This variation may be attributable to the fact that while the federal act mandates the provision of services only to children aged 6 to 18 , it also permits and subsidizes services to children aged 3 to 5 and 18 to 21 if consistent with state law. ${ }^{3}$ Only a few states purport to guarantee something more than an "appropriate" education, such as the "best" or "most appropriate" education. ${ }^{4}$

Several possible explanations exist for these essentially uniform results. Perhaps the federal act has hit upon the most efficacious standard; to provide anything more than an "appropriate" education may bring only marginal returns not commensurate with the additional cost of attaining a higher standard. Furthermore, since the cost of providing special education and related services is already extremely high, the states may not be able to afford to go beyond the minimum requirements. Finally, the availability of the federal court system to parties who wish to appeal a state agency decision has resulted in the creation of certain substantive standards which are applied consistently across federal districts and even circuits throughout the United States.

Only New Mexico has chosen not to participate in the EAHCA. However, because New Mexico's educational institutions receive federal funds under other programs, the state has been required to comply with the regulations promulgated under section 504 of the Rehabilitation Act. ${ }^{5}$ Section 504 prohibits discrimination against handicapped individuals by any program receiving federal financial assistance and has been interpreted to apply in the educational and vocational contexts, as well as in many other areas. ${ }^{6}$ Many of the regulations promulgated under section 504 are substantially similar to those under the EAHCA. ${ }^{7}$ Thus, although it may not have to meet the same due process requirements as states receiving grants directly under the EAHCA, New Mexico is still required to provide a free appropriate public

3. 20 U.S.C. $\S 1412(2)(B)(1982)$.

4. See infra note 48.

5. 29 U.S.C. \& 794 (1982). See New Mexico Ass'n for Retarded Citizens v. New Mexico, 495 F. Supp. 391 (D.N.M. 1980), rev'd on other grounds, 678 F.2d 847 (10th Cir. 1982).

6. See Lora v. Board of Educ., 456 F. Supp. 1211, 1228 (E.D.N.Y. 1978).

7. Compare 34 C.F.R. $\$$ \$ 300.1 - 754 (1984) (promulgated under EAHCA) with 45 C.F.R. $\$ \$ 84.1-$ .61 (1984) and particularly 45 C.F.R. $\$ \S 84.31-.40$ (1984) (promulgated under $\S 504$ of the Rehabilitation Act; requires provision of free appropriate public education to qualified handicapped person). 
education. ${ }^{8}$

II

\section{Eligibility Under State Statutes}

Before a child can request a special placement or other services related to special education, he must establish that he qualifies under the relevant state statute. Most jurisdictions speak in terms of "exceptional children;"9 however, some statutes refer to "children requiring special education," 10 while others speak of "handicapped children"11 or those with "special needs." 12

Factors such as age, handicapping condition, and the extent of a handicap are woven into the definitions of "eligible" children. Special considerations are also made, in some cases, for pregnant or gifted and talented children. While all of the above definitions and descriptive factors are basically within the scope of the EAHCA, some variations from state to state may be noted.

\section{A. Age}

At a minimum, all states follow EAHCA requirements by providing special education services to children aged 6 to $18 .^{13}$ Many state acts raise the upper limit, with the most common maximum age (in twenty-one states) being $21,{ }^{14}$ although six states discontinue coverage at age $20 . .^{15}$ Even those states which do not mandate coverage to the age of 21 often permit local agencies that are able to do so to provide services. ${ }^{16}$

The most common minimum ages (in twenty-six states) for coverage under state statutes are $6^{17}$ and $5 .{ }^{18}$ In some states, the age at which the right to

8. New Mexico Ass'n for Retarded Citizens v. New Mexico, 495 F. Supp. 391, 397-98 (D.N.M. 1980).

9. See, e.g., Ala. Code § 16-39-2(1) (1977); Alaska Stat. \$ 14.30.180 (1982); Ariz. Rev. Stat. Ann. \$ 15-761(2) (1982); Ark. Stat. Ann. \$ 80-2102 (1980); Cal. Educ. Code $\$ 56000$ (West Supp. 1984); Conn. Gen. Stat. Ann. \& 10-76a(c) (West Supp. 1983); Del. Code Ann. tit. 14, $\$ 3101(1)$ (1981); Hawail Rev. Stat. § 301-21 (Supp. 1983); Idaho Code § 33-2002 (1981); Kan. Stat. Ann. $\S 72-962$ (f) (Supp. 1982); Ky. Rev. Stat. ANN. $\$ 157.200(1)$ (Baldwin 1981).

10. See, e.g., Iowa Code AnN. § $281.2(1)$ (West Supp. 1983); N.M. Stat. Ann. $§ 22-8-2(N)$ (Supp. 1984).

11. See, e.g., Md. Educ. Code AnN. \& 8-401(a)(2) (Supp. 1983); Minn. Stat. Ann. \& 120.03 (West 1960 \& Supp. 1984); Mo. AnN. STat. § 162.675(2) (Vernon Supp. 1984); N.J. STAT. AnN. § 18A:46-1 (West Supp. 1984); Or. Rev. Stat. § 343.035(2) (1983); Wash. Rev. Code AnN. § 28A.13.010 (1982).

12. See, e.g., Mass. Ann. Laws ch. $71 \mathrm{~B}, \S 1$ (Law. Co-op. Supp. 1983); N.C. Gen. Stat. § $115 \mathrm{C}-$ 106(b) (1983).

13. 20 U.S.C. $§ 1412(2)(\mathrm{b})$ (1982).

14. See, e.g., Ill. AnN. Stat. ch. 122, § 14-1.02 (Smith-Hurd Supp. 1983); Mass. Ann. Laws ch. $71 \mathrm{~B}, \S 1$ (Law. Co-op. Supp. 1983); Tenn. Code Ann. § 49-10-102(1) (Supp. 1983); Utah Code AnN. §53-18-3 (1981).

15. See, e.g., Conn. Gen. Stat. Ann. § 10-76a(b) (West 1977); Hawair Rev. Stat. § $301-21$ (1976 \& Supp. 1983); Ky. Rev. Stat. AnN. § 157.200(1) (Baldwin 1983); Mo. ANN. Stat. § 162.670 (Vernon Supp. 1984); N.Y. Educ. LAw $\$ 4401$ (McKinney 1981).

16. See, e.g., Mont. Code Ann. $\$ 20-7-412$ (a) (1983).

17. See, e.g., Ala. Code § 16-39-2(1) (Supp. 1983); Ark. Stat. Ann. \$ 80-2124 (1980); Miss Code AnN. \$ 37-23-69(b) (Supp. 1983).

18. See, e.g., Mo. Ann. Stat. \$162.700(1) (Vernon Supp. 1984); Nev. Rev. Stat. \$388.490 
special education accrues depends on whether kindergarten is offered. ${ }^{19} \mathrm{Min}$ imum ages in other states range from four to birth, although many states condition inclusion of these preschool age children upon their ability to benefit from special education or upon the possibility of their handicap worsening without it. ${ }^{20}$ As with the maximum ages, some states make the extended limits mandatory while others merely permit coverage of preschool age children. ${ }^{21}$

\section{B. Handicapping Condition}

Assuming that a child has been able to satisfy the bright-line age requirements, he must still establish that he suffers from what qualifies as a handicapping condition under the applicable state statute. Even though the states' eligibility criteria are all clustered within the requirements of the EAHCA, some variation does exist from state to state. For example, certain learning disabilities will qualify a child for special education under the EAHCA and all state statutes. ${ }^{22}$ In other cases, especially those involving emotional handicaps, the outcome will be neither clear in particular states nor consistent among the states.

What is a state's obligation to a child whose educational performance is above average despite his handicap? Is that child really handicapped within the meaning of the statute? Some states say yes and provide special education. ${ }^{23}$ In fact, one state specifically provides that the handicap need not have any impact on schoolwork. ${ }^{24}$ On the other hand, some states look at subpar academic performance as a key determinant. ${ }^{25}$ Connecticut provides an

(1981) (with exceptions for specified handicaps); S.C. CodE ANN. § 59-63-20 (Law Co-op. Supp. 1983).

19. See, e.g., Ark. Stat. Ann. § 80-2124 (1980); Ariz. Rev. Stat. Ann. § 15-822 (Special Pamphlet 1983); Fla. Stat. AnN. $\$ 232.01$ (West Supp. 1984); 22 Pa. Admin. Code $\$ 13.1$ (1984).

20. See, e.g., Iowa Code AnN. § 281.2(2) (West Supp. 1984) (younger than 5 included if it will help education process when child reaches 5); LA. Rev. Stat. AnN. \& 17:1943(4) (West 1982) (younger than 3 included if handicap could be greatly compounded by time child reaches school age); N.H. Rev. Stat. Ann. § 186-C:2 (Supp. 1983) (minimum age of 3); S.D. Codified Laws AnN. §13-37-1 (1982) (no minimum age).

21. See, e.g., N.J. Stat. ANN. \& 18A:46-6, -6.2 (West Supp. 1984) (mandatory for children ages 35; programs for children under age 3 available through Department of Health and Human Services).

22. See, e.g., 20 U.S.C. \$1401(15) (1982); Ariz. Rev. Stat. ANn. \$15-761(4)(d) (1982); Cal. Educ. Code $\$ 56337$ (West Supp. 1984).

23. See, e.g., Pitts v. Board. of Educ., 568 S.W.2d 595, 597 (Mo. App. 1978) (dictum) (where high I.Q. predicted high academic standing but only average performance was realized due to minimal brain dysfunction, special education was required since child had not developed to maximum capacity); In re Burton Valley School Dist., 1981-82 Educ. HANDICAPPED L. REP. (CRR) 503:256, :258 (Cal. SEA 1982) (special education provided above average student if behavior problems may lead to expulsion and resulting decrease in education).

24. In re Cranston School Dept., 1981-82 Educ. Handicapped L. Rep. (CRR) 503:287, :288 (R.I. SEA 1982) (applying Board of Regents Regulations).

25. See, e.g., Diane K. v. West Jefferson Hills School Dist., 1979-80 Educ. Handicapped L. Rep. (CRR) 501:227, :228 (Pa. SEA 1979) (asthmatic child performing well academically held not "exceptional"); In re Beaverton School Dist., 1979-80 Educ. HandiCAPPEd L. REP. (CRR) 501:375, :376-77 (Or. SEA 1979) (where child was teased by classmates regarding eye condition but academic performance was satisfactory, child was not entitled to special education); In re Gore Pub. Schools, 1981 82 Educ. Handicapped L. ReP. (CRR) 503:179, :180-81 (Okla. SEA 1981) (child not entitled to special education program without showing of significant severe discrepancy between achievement and ability). 
excellent illustration of how a conservative definition of handicap may limit the obligation to provide special education. In that state, average academic performance generally precludes a student from receiving special education services. ${ }^{26}$

Academic progress notwithstanding, another definitional problem is found in the characterization of behavioral and disciplinary problems. California, taking a generous approach, has found an obligation to provide special education to alcoholic truants, ${ }^{27}$ students who did satisfactorily at school but were involved with drugs at home, ${ }^{28}$ students who assaulted classmates, ${ }^{29}$ and students whose parents failed to provide a proper home environment. ${ }^{30}$ There is also some authority that convicted felons may be eligible for special education in at least one state. ${ }^{31}$

Less generous states require a close nexus between the handicap and the learning process itself. In Illinois, for example, problems in the home environment must be related to educational needs in order to qualify as a handicapping condition. ${ }^{32}$ Other states have rejected claims based on a child's need for peer group influence ${ }^{33}$ or on a desire to keep a child out of a Youth Correctional Center. ${ }^{34}$ In order to qualify for special education in many states, a child must demonstrate that he can benefit from that special education even if he is clearly below average academically because of a handicapping condition. ${ }^{35}$

While it is clear that an underlying purpose of the state and federal special education statutes is to extend education to those children who were histori-

26. See S.P., 1980-81 Educ. HANdiCapPed L. REP. (CRR) 502:258, :259 (Conn. SEA 1981) (math whiz with emotional problems not entitled to transportation for college level course); M.N., 1980-81 Educ. Handicapped L. ReP. (CRR) 502:331, :335 (Conn. SEA 1981); B., 1980-81 Educ. HandiCAPPED L. REP. (CRR) 502:286 (Conn. SEA 1981) (M.N. and B. held that where residential placement was for nonacademic reasons, board's obligation was limited to costs of special education). But see O.T., 1980-81 Educ. Handicapped L. ReP. (CRR) 502:292, :294 (Conn. SEA 1981) (suicidal child who was rejected by mother found to have "intertwined" educational and emotional problems and therefore was handicapped).

27. In re Capistrano USD, 1980-81 Educ. HANdiCapped L. ReP. (CRR) 502:129 (Cal. SEA 1980).

28. In re Los Angeles Unified School Dist., 1980-81 Educ. HandiCaPPEd L. REP. (CRR) 502:364 (Cal. SEA 1981).

29. In $r e$ Santa Ana Unified School Dist., 1982-83 Educ. HandiCapped L. ReP. (CRR) 504:151, :152 (Cal. SEA 1982) (reasoning that if expelled, the student would suffer loss of special educational services).

30. In re San Marcos Unified School Dist., 1983-84 Educ. HandiCAPPED L. REP. (CRR) 505:105, :107 (Cal. SEA 1983) (children have right to education regardless of parents' failures).

31. See, e.g., Green v. Johnson, 513 F. Supp. 965, 974 (D. Mass. 1981).

32. Case No. SE-61-82, 1982-83 Educ. HANdicapped L. REP. (CRR) 504:297, :298 (Ill. SEA 1983) (suicidal 14-year-old girl who assaulted mother ineligible); Jeffrey K. v. Concord Carlisle High School, 1979-80 Educ. HandicapPed. L. ReP. (CRR) 501:205, :207 (Mass. SEA 1979) (special education and related services to be provided students with emotional problems when a nexus between the disturbance and inability to make progress in a regular education program is established).

33. In $r e$ R.C., 1981-82 Educ. HANDiCAPPEd L. ReP. (CRR) 503:114, :1 19-20 (Conn. SEA 1981) (Board responsible only for special education costs where residential placement made for noneducational reasons).

34. In re Madison County School Dist., 1981-82 Educ. HANdicapPed L. REP. (CRR) 503:130, :132 (Ga. SEA 1981).

35. See, e.g., 72 Op. Att'y Gen. 652 (Iowa 1982); Kan. Stat. Ann. $§ 72-976$ (1980). 
cally ostracized because of their handicaps, ${ }^{36}$ some statutes extend the definition of a handicapping condition beyond any literal interpretation. For example, although most states make gifted and talented special education discretionary with the local education agency, ${ }^{37}$ some statutes mandate special education for gifted or talented children. ${ }^{38}$ Pregnancy is similarly treated as a handicapping condition in some states. ${ }^{39}$

A review of the statutes and cases indicates that the sine qua non of special education is that the handicap have some sort of impact on classroom performance; however, almost anything in the life of a child may affect his academic progress. For example, a drawn-out custody battle between a child's parents might be reflected in poor performance in school. The variation among the states (and indeed from case to case within a state) may be attributable to the willingness or reluctance of an educational agency to find a nexus and accept responsibility for dealing with a problem that, even though reflected in school work, really is far removed from education. Statutes which are, by necessity, vaguely worded do not provide bright-line guidance as to what is a handicapping condition and, in turn, contribute to the problem of inconsistent coverage.

\section{III}

\section{Level of State Commitment}

Once a state accepts the obligation to provide special education, there remains the question of how far that obligation extends. The federal standard ${ }^{40}$ notwithstanding, the states vary in the level of assistance they provide to handicapped children.

The most common obligation that states have undertaken is to provide an "appropriate" education. ${ }^{41}$ Some states interpret appropriate in terms relative to the handicapped child's needs. ${ }^{42}$ Other interpretations of appropriate education include terms such as "competent,"43 "suitable,"44 or "meaningful" education. ${ }^{45}$ Other states set out their obligations in terms of the

36. 20 U.S.C. $\S 1400$ (1982); S. REP. No. 168, 94th Cong., 1st Sess. 7-9, reprinted in 1975 U.S. Code Cong. \& AD. News, 1425, 1431-33.

37. See, e.g., Hawail Rev. Stat. § 301-33 (Supp. 1983); Md. Educ. Code AnN. § 8-203 (1978); Wash. Rev. Code ANn. § 28A.16.030 (1982).

38. See, e.g., 24 Pa. Cons. Stat. AnN. § 13-1372(3) (Purdon Supp. 1983); S.D. Codified Laws ANN. \& 13-37-25 (1982).

39. See, e.g., Tex. Educ. Code Ann. \$ 16.16(b)(1) (Vernon 1972); Wis. Stat. Ann. $\S 115.76(3)(\mathrm{h})$ (West Supp. 1983).

40. See Board of Educ. v. Rowley, 458 U.S. 176 (1982).

41. See, e.g., Ala. Code $\$ 16-39-3$ (1977); Cal. Educ. Code $\$ 56000$ (West Supp. 1984); MD. Educ. Code Ann. \$ 8-401(3) (Supp. 1983); N.H. Rev. Stat. Ann. § 186-C:1 (Supp. 1983); Ohio Rev. Code AnN. §§ 3323.01, .02 (Page Supp. 1983); S.C. Code AnN. \$ 59-33-10 (Law. Co-op. 1977); VA. CODE $\S 22.1-214-A$ (Supp. 1984).

42. See, e.g., Ark. Stat. Ann. \& 80-2117 (1980); N.M: Stat. Ann. § 22-13-5 (1984); Wash. Rev. Code Ann. § 28A.13.010 (1982); 22 Pa. Admin. Code $\$ 13.1$ (1984).

43. See, e.g., Alaska Stat. \$14.30.180 (1982); Ark. Stat. Ann. $\$ 80-2101$ (1980); Miss. Code ANN. § 37-23-1 (Supp. 1983).

44. See, e.g., N.J. Stat. Ann. \& 18A:46-13 (West Supp. 1984).

45. See, e.g., Neb. Rev. Stat. \$ 43-641 (1978). 
potential or capabilities of handicapped children, ${ }^{46}$ while some states take a quasi-equal-protection position, directing their education agencies to provide equivalent opportunities to handicapped and nonhandicapped children. ${ }^{47} \mathrm{~A}$ few states, in providing for the maximum or "best" education, imply a commitment to exceed the federal mandate. ${ }^{48}$ It is clear, however, that no state is obligated to provide a utopian educational program. ${ }^{49}$ Notwithstanding these facially varying levels of commitment, no clear difference can be found among the states in the actual provision of day-to-day services. ${ }^{50}$

Of course, vague definitions and policies are not in themselves very important to handicapped children. What is important to these children is the degree of special education that they receive. Various provisions for related services, mainstreaming, year-round placements, homebound instruction, and unilateral placements reflect this concern.

\section{A. Related Services}

While all states provide the related services required by the EAHCA, ${ }^{51}$ some states exceed the minimum standards. The general eligibility test inquires into the extent to which a related service will help the child benefit

46. See, e.g., Kan. STat. ANN. § 72-962(f) (Supp. 1983) (enable them to progress toward maximum of abilities); MASS. ANN. LAwS ch. 71 B $\S 2$ (Law. Co-op. Supp. 1983) (maximum possible development); Mich. Comp. Laws ANN. § 380.1701(a) (West Supp. 1983) (maximum potential); Mo. ANN. STAT. § 162.670 (Vernon Supp. 1983) (maximize capabilities); TenN. Code ANN. \$ 49-10-101 (Supp. 1983) (maximize capabilities).

47. See, e.g., Iowa Code ANN. $\$ 281.2(2)$ (West Supp. 1984) (commensurate with nonhandicapped children); ME. Rev. Stat. ANN. tit. 20A, § 7201(1) (1983); Nev. Rev. Stat. \$ 388.450 (1983) (reasonably equal educational opportunity).

48. See Iowa Code ANN. $\$ 281.2$ (West Supp. 1984) (special education opportunities sufficient to meet the needs and maximize the capabilities of children); Mich. Comp. LAws ANN. $\$ 380.1701$ (West Supp. 1984-85) (to develop the maximum potential of every handicapped person); Mo. ANN. STAT. $\$ \S 162.670, .675(4)$ (Vernon Supp. 1984) (to meet the needs and maximize the capabilities of handicapped children); R.I. GEN. LAws § 16-24-1 (1981) (special education that will best satisfy the needs of the handicapped child). See also Geis v. Board of Educ., 589 F. Supp. 269 (D.N.J. 1984) (standard in New Jersey regulations requires provision of services according to how the pupil can best achieve educational success); In re Traverse Bay Intermediate School Dist., 1982-83 Educ. HaNdiCAPPED L. REP. (CRR) 504:140, :142 (Mich. SEA 1982) (to develop maximum potential); Finn, Advocating for the Most Misunderstood Minority: Securing Compliance with Special Education Laws, 14 SUFFoLk U.L. REv. 505, 517 (1980) (examining Rhode Island law); Note, Damages Actions for Denials of Equal Educational Opportunities, 45 Mo. L. Rev. 281, 297 (1980) (Missouri law requires development to maximum capacity).

49. See, e.g., Lang v. Braintree School Comm., 545 F. Supp. 1221,1227 (D. Mass. 1982) (this court may not interfere where the state is providing the child with an education that is of some benefit and is utilizing a minimally acceptable educational approach, citing Rowley); Bales v. Clarke, 523 F. Supp. 1366, 1370-71 (E.D. Va. 1981) (an "appropriate" education is not synonymous with the best possible education); Case No. SE-99-80, 1982-83 Educ. HaNdiCAPPED L. ReP. (CRR) 504:267, :268 (Ill. SEA 1983); Victoria P. v. Springfield School Dist., 1980-81 Educ. HandicapPed L. REP. (CRR) 502:174, :175 (Pa. SEA 1980) (school district's duty is to provide an appropriate education, not one which affords plaintiff an opportunity to "achieve her utmost potential").

50. See, e.g., Case No. H-0152, 1982-83 Educ. HandiCapped L. ReP. (CRR) 504:368, :369 (Mich. SEA 1983) ("If the maximum potential standard is reachable, it will be achieved only after a program has been designed to meet the unique educational needs of the handicapped child.").

51. See 20 U.S.C. $\$ \S 1401(17), 1412(2)$ (1982); see also Ala. Code $\$ 16-39-2(6)$ (1977); CaL. Educ. Code $\S 56031$ (g) (West 1978); N.C. Gen. Stat. $\S 115 \mathrm{C}-108$ (1983). 
from special education. ${ }^{52}$ The test results in different outcomes depending on the jurisdiction. Numerous examples of these varying outcomes exist. For instance, while psychological and counseling services are provided in some states $^{53}$ (even for parents ${ }^{54}$ ), others find the connection between education and psychological treatment tenuous and do not provide psychotherapy. ${ }^{55}$ Likewise, school boards usually have only a limited responsibility to provide medical care. ${ }^{56}$ Some states, however, provide medical care where essential to school attendance. ${ }^{57}$

Residential placements provide another example of how states implement federal policy. Whether a child receives a residential placement is a function of his needs. ${ }^{58}$ Although many states provide funding for room and board, ${ }^{59}$ at least one state does not recognize an obligation to pay for the cost of raw food. ${ }^{60}$ In other circumstances, the obligation to provide related services has been found to mandate music therapy ${ }^{61}$ and vocational training ${ }^{62}$ but not a

52. See, e.g., In re E.F., 1981-82 Educ. Handicapped L. ReP. (CRR) 503:300, :304 (Conn. SEA 1982); Lorrie v. Natick Pub. Schools, 1979-80 Educ. HandiCaPPEd L. ReP. (CRR) 501:366,:367 (Mass. SEA 1980) (service directly related to success of IEP).

53. See, e.g., In re Palm Springs Unified School Dist., 1980-81 Educ. Handicapped L. REP. (CRR) 502:279 (Cal. SEA 1981). Several states' statutes include psychological, counseling, and/or social work services among those related services provided to handicapped children when appropriate. See, e.g., Colo. Rev. STat. \$ 22-20-1 14(b)(III) (Supp. 1983) (reimbursable costs include consultation and evaluation services by psychiatrists, psychologists, and social workers); IDAHO CODE $\$ 33-2002 A$ (1981); Ky. Rev. Stat. ANn. \$ 157.200(4) (1981); La. Rev. Stat. AnN. \$ 17:1943(3) (1982); Ohio Rev. Code AnN. $\$ 3323.01$ (Page Supp. 1983).

54. See, e.g., Lorrie v. Natick Pub. Schools, 1979-80 Educ. HandicapPed L. ReP. (CRR) 501:366, :367 (Mass. SEA 1979) (test for including psychotherapy in IEP is directness of relationship of the services to success of the IEP). There are several states which provide for counseling, social work, or training services for a handicapped child's parent or guardian as well as for the child. See, e.g., ConN. Gen. Stat. Ann. $\S 10-76 a(h)$ (West Supp. 1983); Mass. Ann. Laws ch. 71 B, $\$ 3$ (Law. Co-op. Supp. 1984); Mo. Ann. Stat. § 162.675(4) (Vernon Supp. 1984); N.C. Gen. Stat. § 115 C-108 (1983); Wis. STAT. ANN. § 115.83(3) (West Supp. 1983-84).

55. See, e.g., In re "A" Family, 184 Mont. 145, 159, 602 P.2d 157, 166 (1979) (finding that state statute would not provide therapy; therefore federal act, which would, applies); Case No. SE-14-83, 1982-83 Educ. HANdicapped L. ReP. (CRR) 504:363, :365 (Ill. SEA 1983); see also Wegner, Variations on a Theme-The Concept of Equal Educational Opportunity and Programming Decisions Under the Education for All Handicapped Children Act of 1975, LAw \& Contemp. Probs., Winter 1985, at 169.

56. See 20 U.S.C. \$ 1412 (1982); see, e.g., In re Tredyffrin-Eastown School Dist., 1981-82 Educ. Handicapped L. ReP. (CRR) 503:245, :246-47 (Pa. SEA 1982) (public school not responsible for medical care); CAL. Educ. Code $\$ 56345.5$ (West Supp. 1984) (prescription of health care not authorized); IND. CoDE ANN. $\$$ 20-1-6-8 (Bobbs-Merrill 1975) (health care is responsibility of family physician or Department of Public Welfare).

57. See, e.g., Department of Educ. v. Katherine D., 531 F. Supp. 517 (D. Hawaii 1982) (tracheotomy cleaning required even where teachers grieved under contract that they were not required to provide such service), modified 727 F.2d 809 (9th Cir. 1984); $c f$. Tatro v. Texas, 703 F.2d 823 (5th Cir. 1983), aff'd in part, rev'd in part sub nom. Irving Indep. School Dist. v. Tatro, 104 S. Ct. 3371 (1984) (must provide catheterization, which is not a medical service).

58. Compare Bill D., 1980-81 Educ. Handicapped L. Rep. (CRR) 502:259, :262 (Conn. SEA 1981) (residential placement not for educational reasons) with San Francisco Unified School Dist. v. State Dep't of Educ., 131 Cal. App. 3d 54, 71 , 182 Cal. Rptr. 525, 536 (1982) and In re Palo Alto City Unified School Dist., 1980-81 Educ. Handicapped L. ReP. (CRR) 502:186, :187 (Cal. SEA 1980) (residential placement for educational reasons).

59. See, e.g., Del. Code ANN. tit. 14, § 3124(c)(1) (1981).

60. 62 Op. Att'y Gen. 353 (Md. 1977).

61. In re Cambridge Public Schools, 1981-82 Educ. Handicapped L. ReP. (CRR) 503:136 (Mass. 
place on the wrestling team. ${ }^{63}$

\section{B. Mainstreaming}

In accordance with the EAHCA requirement, all of the states have obligated themselves to provide handicapped children an education in the least restrictive environment (LRE) possible. ${ }^{64}$ The most common statutory language directs regular classroom placement unless, even with supplemental services, special education cannot be satisfactorily provided in that setting. ${ }^{65}$ Other states simply mandate the use of least restrictive environments, or placement with nonhandicapped children, to the maximum extent possible. ${ }^{66}$ However, the LRE placement need not be the one nearest the student's home, ${ }^{67}$ nor does it necessarily require placement with children of the same age. ${ }^{68}$

While it is clear that an LRE is part of an appropriate education, ${ }^{69}$ there are countervailing considerations which affect placement. ${ }^{70}$ For example, placement in a classroom with nonhandicapped students may require a handicapped child to forego the better facilities and specially trained staff available in a separate special education classroom or school. Some states therefore allow mainstreaming in nonacademic activities where academic mainstreaming is not possible, ${ }^{71}$ and no state allows students to be endangered by mainstreaming. ${ }^{72}$ Given such complications, it is not surprising that the federal standard has been difficult to implement with anything approaching uniformity.

SEA 1981) (although hearing officer did not find music therapy appropriate in this case, officer notes it has been used for other handicapped children).

62. See, e.g., Brindisi v. Passave Valley Regular High School, 1983-84 Educ. Handicapped L. ReP. (CRR) 505:192, :194 (N.J. SEA 1983); CaL. Educ. Code $\$$ 56345(b)(2) (West Supp. 1984).

63. Poole v. South Plainfield Bd. of Educ., 490 F. Supp. 948 (D.N.J. 1980) (decided under federal law).

64. 20 U.S.C. \$ 1412(5)(B) (1982). See, e.g., In re Katherine, 1979-80 Educ. HandiCapped L. REP. (CRR) 501:237, :239 (Md. SEA 1979); Janet H. v. School Dist., 1979-80 Educ. HaNdiCAPPED L. ReP. (CRR) 501:163 (Neb. SEA 1979); Ala. Code \$ 16-39-8 (1976); S.D. Codified Laws ANN. \& 1337-2 (1982); Wis. Stat. AnN. § 115.85(2)(d) (West Supp. 1983).

65. See, e.g., Ariz. Rev. Stat. Ann. \& 15-764(A)(3) (1982); Ark. Stat. Ann. § 80-2118 (1980); Cal. Educ. Code $\$ 56345$ (b)(6) (West Supp. 1984); Colo. Rev. Stat. \$ 22-10-103(5.5) (1982); Iowa Code Ann. \$ 281.2(2) (West Supp. 1984); La. Rev. Stat. Ann. \$ 17:1946B (West 1982); Me. Rev. Stat. AnN. tit. 20A, \& 7201(2) (1983); Minn. Stat. AnN. § 120.17, subd. 3a (West Supp. 1984).

66. See, e.g., Ill. AnN. STAT. ch. 122, \& 14-8.02(c) (Smith-Hurd Supp. 1984-85); Mo. AnN. Stat. $\S 162.680$ (Vernon Supp. 1983); Ohio Rev. Code Ann. § 3323.04 (Page Supp. 1984); Tenn. Code ANN. $\$ 49-10-103$ (c) (1983).

67. In re Cabarrus County Schools, 1980-81 Educ. HandiCapped L. ReP. (CRR) 502:218, :220 (N.C. SEA 1980).

68. In re Marin County Office of Educ., 1982-83 Educ. HANDiCaPPEd L. ReP. (CRR) 504:162, : 165 (Cal. SEA 1982).

69. See 20 U.S.C. $\$ \S 1401(18), 1401(19), 1412(5)$ (1982).

70. See, e.g., In re Mathew S., 1980-81 Educ. HANdiCAPPEd L. ReP. (CRR) 502:346 (Mass. SEA 1981) (need for deaf role models found more important than mainstreaming).

71. See, e.g., Cincinnati City School Dist., 1980-81 Educ. Handicapped L. Rep. (CRR) 502:117, :119-20 (Ohio SEA 1979) (mainstream in nonacademic activities where handicap warrants removal from ordinary academic environment).

72. See, e.g., A.M.M. v. Board. of Educ., 1979-80 Educ. Handicapped L. ReP. 501:304 (N.J. SEA 1979). 


\section{Year-Round Services}

The question whether local school districts can be required to provide educational services for exceptional children for more than the traditional 180-day school year has been the subject of much litigation. As a result of a federal court decision interpreting requirements under the EAHCA, the response from states has been fairly uniform. Battle $v$. Pennsylvania ${ }^{73}$ held that Pennsylvania's policy of refusing to provide or fund education for more than 180 days per year for any child, whether handicapped or nonhandicapped, violated the federal act. The court focused on the Act's requirement of a free appropriate public education designed to meet the unique needs of a handicapped child. ${ }^{74}$ The court of appeals acknowledged the district court's finding that because of regression and the length of time required to recoup lost skills and behaviors, interruptions in programming brought about by the 180-day rule render it impossible or unlikely that mentally retarded children will attain the objectives of their individualized education programs. ${ }^{75}$ Pennsylvania's categorical refusal to consider the needs of each individual student therefore violated federal policy. ${ }^{76}$ Similar categorical refusals to consider providing more than 180 days of service have been found invalid in other states under the EAHCA. ${ }^{77}$

As a result of the above decisions, it appears that all states must provide more than 180 days of educational services where the unique needs of a child require such instruction as part of a free appropriate public education. To this end, several state codes allow the provision of year-round services where required..$^{78}$ Other states have expressly complied with the federal policy either through case law or through administrative decisions. ${ }^{79}$

Most courts apply a "substantial regression" standard to determine which exceptional students are entitled to a year-round program, holding that the handicapped child is not entitled to a summer placement at the school district's expense unless his parents can demonstrate that the child would regress substantially without such a program. ${ }^{80}$ Some of these courts have

73. 629 F.2d 269 (3d Cir. 1980), cert. denied, 452 U.S. 968 (1981).

74. Id. at 276 .

75. Id at 275 .

76. Id. at $\mathbf{2 8 0 .}$.

77. See Crawford v. Pittman, 708 F.2d 1028 (5th Cir. 1983) (Mississippi); Yaris v. Special School Dist., 558 F. Supp. 545 (E.D. Mo. 1983); Georgia Ass'n of Retarded Citizens v. McDaniel, 511 F. Supp. 1263 (N.D. Ga. 1981), affd, 716 F.2d 1565 (11th Cir. 1983).

78. See, e.g., Alaska Stat. \$14.30.350(2) (1982); Minn. Stat. Ann. $\$ 120.17$, subd. 5a (West Supp. 1984) N.H. Rev. Stat. ANN. \& 186-C:15 (Supp. 1983) (if interruption of program would result in severe and substantial harm and regression); N.D. Cent. CODE $\$ 15-59-02.1$ (1981) (if required in child's individualized education program (IEP) and interruption would cause regression); OKLA. Stat. ANN. tit. 70, § 13-101 (Supp. 1983-84) (extension not to exceed 40 days in summer months and only if for severely or profoundly multiple-handicapped student whose IEP states need for continuing program); Wts. STAT. ANN. \$115.83(4) (West Supp. 1983) (may include summer program).

79. See cases cited infra notes $80-84$. These cases were decided pursuant to both state and federal law unless otherwise noted.

80. See, e.g., Rettig v. Kent City School Dist., 539 F. Supp. 768, 778-79 (N.D. Ohio 1981), affd in part and vacated in part, 720 F.2d 463 (6th Cir.), cert. denied, 104 S. Ct. 2379 (1984) (federal act only); Bales v. Clarke, 523 F. Supp. 1366 (E.D. Va. 1981) (irreparable loss of progress); In re S., 1980-81 
also considered an additional "recoupment" component, examining whether the child requires inordinately more time than nonhandicapped children to regain lost skills. ${ }^{81}$ Following Battle v. Pennsylvania and its interpretation of the EAHCA, many states have fashioned similar standards for determining a handicapped child's eligibility for summer educational services. These standards acknowledge the state's obligation to provide an appropriate education which meets a student's individual needs, including year-round educational services where necessary. ${ }^{82}$

New York has a unique dual system for providing educational services to exceptional children beyond the regular school year. While the school district ordinarily is required to provide services for only the traditional 10-month school year, parents may petition the family court for an order to provide educational services during the summer months. ${ }^{83}$ One drawback is that the parent or guardian in New York is inconvenienced by the necessity of petitioning both the commissioner of education and the family court each year. ${ }^{84}$

\section{Homebound Services}

One useful measure of a state's compliance with the federal act is its willingness to provide services for exceptional children who are homebound. The majority of states give a passing acknowledgment to homebound instruction by incorporating homebound and hospital instructional services into their definition of special education, as is done in the EAHCA. ${ }^{85}$ Several states go a step further and include homebound instruction by visiting teachers in their statutory listing of alternative services, placements, or means for delivering services. ${ }^{86}$ Those few jurisdictions which attempt to define the circumstances under which homebound services may be provided generally

Educ. HANdicapped L. ReP. (CRR) 502:362, :363-64 (Conn. SEA 1981); In re Jay R., 1983-84; Educ. Handicapped L. ReP. (CRR) 505:123, :126 (Mass. SEA 1983); In re Canton Pub. Schools, 1981-82 Educ. Handicapped L. ReP.; 503:235 (Mass. SEA 1982) (cases decided under state statutes and regulations); see also Anderson v. Thompson, 495 F. Supp. 1256, 1265 (E.D. Wis. 1980), affd, 658 F.2d 1205 (7th Cir. 1981).

81. See cases cited supra note 80; N.D. Cent. Code $\$ 15-59-02.1$ (1981).

82. See, e.g., Birmingham School Dist. v. Superintendent of Pub. Instruction, 120 Mich. App. 465, 474-76, 328 N.W.2d 59, 63 (1982); Mahoney v. Admin. School Dist. No. 1, 42 Or. App. 665, 670, 601 P.2d 826, 828 (1979); In re J.B., 1981-82 Educ. HANDiCAPPEd L. REP. (CRR) 503:289, :290 (Nev. SEA 1980); In re Lake Oswego School Dist., 1979-80 Educ. Handicapped L. ReP. (CRR) 501:344, :345 (Or. SEA 1980).

83. In re Frank G., 98 Misc. 2d 837, 842, 414 N.Y.S.2d 851, 855 (N.Y. Fam. Ct. 1979); N.Y. EDUC. LAW $\S \S 4401-4409$ (McKinney 1981).

84. In re Dwella P., 98 Misc. 2d 869, 414 N.Y.S.2d 878 (N.Y. Fam. Ct. 1979).

85. 20 U.S.C. $\$ 1401(16)$ (1982); see, e.g., Ala. Code $\$ 16-39-7$ (1977); Mont. Code AnN. $\$ 20-7-$ 401(12) (1983); N.Y. Educ. Law $\S 4401$ (McKinney 1981 \& Supp. 1983); S.C. Code ANN. § 59-3320(c) (Law. Co-op. 1977); VA. Code § 22.1-213.2 (Supp. 1984).

86. See Neb. Rev. Stat. \$43-607(3) (1978 \& Cum. Supp. 1982); Okla. Stat. Ann. tit. 70, § 13103 (West 1972) (when exceptional or pregnant child is unable to attend any school or class in the district); 24 Pa. Cons. Stat. Ann. § 13-1372(3) (Purdon Supp. 1983) (the regulations promulgated hereunder specify homebound instruction as being within a school district's special educational program, 22 Pa. Admin. Code § 13.11(d) (1984)); Vt. Stat. AnN. tit. 16, § 2944(a) (1982) (for those temporarily or permanently homebound or hospitalized when private instruction will best serve the interest of such persons). 
require that a child be physically unable to attend any school ${ }^{87}$ and that a physician so certify. ${ }^{88}$

The current lack of specific statutory limitations on the provision of homebound services may be attributable to the fact that there has been little litigation on the subject. Since a child's home is one of the most restrictive environments in which services can be provided, homebound services presumably are used only as a last resort or as a temporary placement while the school district seeks a more appropriate permanent placement. The few cases which do discuss homebound services recognize this situation and impose conditions similar to those found in the statutory law. ${ }^{89}$

\section{E. Unilateral Placement}

The heart of the EAHCA is in the section delineating procedural safeguards.90 Rather than defining an "appropriate education" in the abstract, the Act ensures that the content of a free appropriate public education is decided upon in a particular case through the participation of the child's parents, the local educational agency, and educational and medical experts. ${ }^{91}$ Accordingly, parents and school districts are required to follow strict procedural rules throughout the placement process. ${ }^{92}$ Failure to abide by these rules may result in shifting the financial responsibility for an educational placement from the school district to the parents, or vice versa. This shifting of costs frequently arises as a result of "unilateral placements" made by the child's parents or guardian. A unilateral placement occurs when the parent places the child in an educational facility or environment which has not been approved by the local educational agency.

Due to the mandatory nature of the federal procedural safeguards, judicial responses to unilateral placements are fairly uniform across the nation. One well-established point is that a local school district will not be liable for the

87. OHIo REv. Code $\$ 3323.12$ (1980 \& Supp. 1983) (for handicapped children of compulsory school age who are unable to attend school, even with the help of special transportation).

88. W. VA. CoDE $\$ 18-20-1$ (1984) (to be provided after July, 1983 for children who are homebound due to injury or who for any other reason as certified by a licensed physician are homebound for a period of more than 3 weeks); Wis. STAT ANN. $\$ 115.85(2)(e)$ (West Supp. 1983) (placement at child's home or residence if there is a physician's statement in writing that the child is unable to attend school); see also Ariz. Rev. Stat. ANN. \$ 15-761(c) (1983 Special Pamphlet) (defining "homebound" child).

89. Case No. SE-17-83, 1982-83 Educ. Handicapped L. ReP. (CRR) 504:353, :354 (Ill. SEA 1983) (citing the following state regulatory criteria for homebound services: 1) absence from school for 2 weeks to 6 months; 2 ) certification by a licensed medical doctor that the student has a health or physical impairment which will require such absence; and 3) determination by school personnel that student can benefit from services); In re Stoneham Pub. Schools, 1981-82 Educ. HandiCapped L. REP. (CRR) 503:207 (Mass. SEA 1982) (requiring that severely multiple-handicapped child be provided occupational, physical, and speech therapy in home pursuant to physician's judgment that placement in hospital program was threatening to child's health).

90. 20 U.S.C. $\$ 1415$ (1982).

91. See, e.g., Lora v. Board of Educ., 456 F. Supp. 1211, 1227, 1234-42 (E.D.N.Y. 1978), vacated, 623 F.2d 248 (2d Cir. 1980); Case No. 25, 1979-80 Educ. HandiCapPed L. ReP. (CRR) 501:110,:111 (Wis. SEA 1979).

92. See 20 U.S.C. $\$ 1415$ (1982); 34 C.F.R. $\S \S 300.500-.589$ (1984). 
costs of a unilateral placement when the school district first attempts in good faith to provide an appropriate placement and services for a handicapped child. ${ }^{93}$ A school district has no legal obligation to reimburse parents if it offers an appropriate publicly provided placement which the parents refuse. ${ }^{94}$ A parent may also be denied reimbursement if he places the child without ever requesting a placement from the local education agency. ${ }^{95}$

Many unilateral placement cases are tied closely to the "status quo" provision of the federal act. ${ }^{96}$ This provision requires that a child remain in his then current educational placement during the pendency of any due process proceedings unless the state or local educational agency and the parents or guardian agree otherwise. ${ }^{97}$ Thus, parents generally are not entitled to reimbursement if they change the child's placement, either without the school district's consent during the pendency of the proceedings, ${ }^{98}$ or without first pursuing the appropriate administrative procedures. ${ }^{99}$ Correspondingly, a school district which changes a handicapped child's placement in violation of the status quo provision will be liable for the costs incurred by the parents'

93. See, e.g., Flavin v. Connecticut State Bd. of Educ., 553 F. Supp. 827, 832-33 (D. Conn. 1982) (federal law only); Lux v. Connecticut State Bd. of Educ., 34 Conn. Supp. 257, 386 A.2d 644, 647 (Conn. Super. Ct. 1982); In re Newport Mesa Unified School Dist., 1981-82 Educ. Handicapped L. ReP. (CRR) 503:186, :187 (Cal. SEA 1982); Case No. 36-82, 1982-83 Educ. Handicapped L. ReP. (CRR) 504:250,:253 (Ill. SEA 1982). Note that the cases cited infra notes 94-106, were decided under either state law or both state and federal law unless otherwise noted.

94. See, e.g, Stacey G. v. Pasadena Indep. School Dist., 695 F.2d 949, 954 (5th Cir. 1983) (also discusses state regulation comparable to federal "status quo" provision); Fitz v. Intermediate Unit \#29, 43 Pa. Commw. 370, 403 A.2d 138, 141 (1979) (absent showing that placement was inappropriate, state secretary of education justified in denying tuition reimbursement for unilateral placement); Case No. 9953, 1979-80 Educ. Handicapped L. ReP. (CRR) 501:120, :121 (N.Y. SEA 1979); Scott B. v. Harlingen Consol. Indep. School Dist., 1982-83 Educ. HandiCapped L. ReP. (CRR) 504:344, :349 (Tex. SEA 1983); In re Todd B., 1979-80 Educ. HANdicapPed L. ReP. (CRR) 501:165 (Wash. SEA 1979) (affirming local hearing officer's finding that school had offered four appropriate program alternatives and denying private placement at public expense).

95. See, e.g., Welsch v. Commonwealth, 42 Pa. Commw. 41, 44, 400 A.2d 234, 235 (1979); In re New York City School Dist., 1982-83 Educ. HandiCapped L. ReP. (CRR) 504:178, :178-79 (N.Y. SEA 1982).

96. See infra notes 98-100.

97. 20 U.S.C. $\$ 1415(\mathrm{e})(3)$ (1982).

98. See Mt. View-Los Altos Union High School Dist. v. Sharon B.H., 1983-84 Educ. HANDiCAPPED L. REP. (CRR) 555:113 (9th Cir. 1983) (federal law only); Stemple v. Board of Educ., 623 F.2d 893 (4th Cir. 1980), cert. denied, 450 U.S. 911 (1981) (federal law); Cain v. Yukon Pub. Schools, 556 F. Supp. 605 (W.D. Okla. 1983) (federal law); Lillian S. v. Ambach, 92 A.D.2d 979, 461 N.Y.S.2d 501 (1983); Newport-Mesa Union School Dist. v. Hubert, 132 Cal. App. 3d 724, 730, 183 Cal. Rptr. 334, 338 (1982); Case No. 82-162, 1982-83 Educ. Handicapped L. Rep. (CRR) 504:133 (Cal. SEA 1982). But of. Doe v. Anrig, 561 F. Supp. 121 (D. Mass. 1983), affd, 728 F.2d 30 (1st Cir. 1984) (ordering reimbursement where court upheld parent's unilateral placement decision); Doe v. Brookline School Comm., 722 F.2d 910 (1st Cir. 1983) (holding reimbursement available to the prevailing party under authority of 20 U.S.C. $\$ 1415(\mathrm{e})(2))$. For a discussion of the challenges to the Doe $v$. Brookline interpretation of the status quo provision, see generally Osborne, Reimbursement Under the EAHCA for Unilaterally Obtained Private Schooling: The Implications of Doe $v$. Brookline, 19 EDUC. L. REP. 469 (West 1984).

99. See In re Los Angeles Unified School Dist., 1980-81 Educ. Handicapped L. REP. (CRR) $502: 381,: 382$ (Cal. SEA 1981) (no reimbursement, absent irreparable harm or unreasonable delay, if parents have not exhausted administrative remedies); Case No. 10686, $1981-82$ EduC. HANDiCAPPED L. REP. (CRR) 503:124 (N.Y. SEA 1981) (parents not entitled to reimbursement for unilateral placement without first pursuing the appropriate administrative procedures). 
subsequent unilateral placement. ${ }^{100}$

A handicapped child's parents are also entitled to reimbursement for a unilateral placement that was necessitated by an educational agency's conscious failure or refusal to provide a free appropriate public education ${ }^{101}$ or by other procedural violations, such as an unreasonable delay in providing services. ${ }^{102}$ Some courts have also held that a parent who takes action to protect his child's physical health from a threatening situation may be entitled to damages or reimbursement. ${ }^{103}$ Likewise, if the school district places a child inappropriately, the district may have to bear the expense of a unilateral placement by the parents. ${ }^{104}$ On the other hand, parents who make a unilateral placement take the risk of making an inappropriate choice themselves and thereby assume the risk of being reimbursed only partially or not at all. ${ }^{105}$

\section{F. Graduation}

A recurring point of contention concerns whether handicapped children are entitled to a diploma upon completion of their education. Receiving a diploma is a particularly compelling concern for many of the less severely handicapped because it affects their prospects for obtaining employment after they leave school. A few states have enacted statutes that authorize school boards to issue a diploma or certificate of graduation to exceptional children. ${ }^{106}$ For the most part, these statutes merely empower the school district

100. In re Ramsey County School Dist., 1981-82 Educ. Handicapped L. ReP. (CRR) 503:304, :305 (Minn. SEA 1981) (dropping handicapped child from high school membership rolls constituted a change in placement); Deist v. Adams Cent. School Dist. No. 090, 1980-81 Educ. HandicapPed L. REP. (CRR) 502:241 (Neb. SEA 1980).

101. See, e.g., Adams Cent. School Dist. v. Deist, 214 Neb. 307, 334 N.W.2d 775, 785 (1983) (school district which fails to provide a free appropriate public education is liable to reimburse parent who does obtain such services); New York City Bd. of Educ. v. Ambach, 88 A.D.2d 1075, 1076, 452 N.Y.S.2d 731, 733 (1980); In re Board of Educ., 1983-84 Educ. HandiCAPPEd L. REP. (CRR) 505:142, :144 (N.Y. SEA 1983).

102. See, e.g., New York City Bd. of Educ. v. Ambach, 88 A.D.2d 1075, 452 N.Y.S.2d 731, 734 (N.Y. App. Div. 1982) (ordering reimbursement where content and time requirements for formal notice of rejection not met); Jose P. v. Ambach, 1981-82 Educ. Handicapped L. ReP. (CRR) 553:298 (E.D.N.Y. 1982) (upholding 1977 order of Commissioner of Education that permits parents unilaterally to place children who have not been placed within 60 days of referral for evaluation and requires New York City to bear expense); In re Worcester Pub. Schools, 1981-82 Educ. Handicapped L. ReP. (CRR) 503:166, :169 (Mass. SEA 1981) (failure to offer timely appropriate placement).

103. See Anderson v. Thompson, 658 F.2d 1205, 1214 (7th Cir. 1981) (federal law only); Walker v. Cronin, 107 Ill. App. 3d 1053, 1059 , 438 N.E.2d 582, 587 (1982).

104. Amherst-Pelham Regional School Comm. v. Department of Educ., 376 Mass. 480, 493, 381 N.E.2d 922, 931 (1978).

105. See, e.g., Blomstrom v. Massachusetts Dep't of Educ., 532 F. Supp. 707, 713 (D. Mass. 1982) (school district obligated to pay for only day portion of residential placement; court says dispute is governed by federal law); Board of Educ. v. Connecticut Bd. of Educ., 179 Conn. 694, 703, 427 A.2d 846, 851 (1980); In re Worcester Pub. Schools, 1981-82 Educ. Handicapped L. REP. (CRR) 503:166, :169 (Mass. SEA 1981).

106. Ill. ANN. STat. ch. 122, § 14-6.01 (Smith-Hurd Supp. 1983) (no handicapped child may be denied promotion, graduation, or a general diploma on the basis of failing minimal competency test when failure of such test directly related to handicapping condition); IND. CODE ANN. \$ 20-1-6-17 (Michie Bobbs-Merrill Supp. 1984) (authorized to issue to handicapped child completing special education program); 22 PA. Admin. Code $\$ 13.15$ (1984) (under state law, exceptional child who satisfactorily completes special education program is entitled to a high school diploma, except trainable or profoundly mentally retarded, who are entitled to a certificate of graduation). 
to issue a diploma or certificate, leaving the decision whether to do so to the discretion of the school. ${ }^{107}$ This discretion has been held to be permissible, since the denial of a high school diploma to handicapped children does not violate the EAHCA ${ }^{108}$ or section 504 of the Rehabilitation Act. ${ }^{109}$ While the federal acts ensure that a student is provided access to an appropriate education, they do not guarantee that the student will successfully reach the level of academic achievement necessary for the award of a diploma. In addition, courts have observed that a state has a legitimate interest in restricting the issuance of diplomas to ensure the value of the diplomas in the community and to improve the general quality of education. ${ }^{110}$ In cases where a handicapped child is not given sufficient advance notice of the requirements for obtaining a diploma, however, a school district violates the child's right to due process. ${ }^{111}$

In some states, a school district may terminate educational services when the handicapped child becomes eligible for graduation from high school or reaches a certain age, whichever occurs first. ${ }^{112}$ Although these states do not specifically address the question of eligibility for a diploma, they do imply, through their criteria for determining when special education services will be terminated, that exceptional students may receive a diploma or other certification of graduation from high school.

A related question concerns the time at which a school district may terminate special education services and programs for exceptional children. As noted above, in some states educational services may be terminated when a handicapped student either becomes eligible to graduate from high school or

107. See In re Peoria School Dist. \# 150, 1980-81 Educ. HandiCaPPEd L. ReP. (CRR) 502:299 (IIl. SEA 1981).

108. Brookhart v. Illinois State Bd. of Educ., 697 F.2d 179 (7th Cir. 1983).

109. 29 U.S.C. $\$ 794$ (1982); Board of Educ. v. Ambach, 107 Misc. 2d 830, 436 N.Y.S.2d 564 (Sup. Ct. 1981), modified, 90 A.D.2d 227, 458 N.Y.S.2d 680 (1982), affd, 60 N.Y.2d 758 , 457 N.E.2d 775 (1983) (both acts); In re Peoria School Dist. \# 150, 1980-81 Educ. Handicapped L. REP. (CRR) 502:299 (Ill. SEA 1981) (both acts).

110. Board of Educ. v. Ambach, 107 Misc. 2d 830, 835, 436 N.Y.S.2d 564, 569, modified, 90 A.D.2d 227, 458 N.Y.S.2d 680 (1982), affd, 60 N.Y.2d 758, 457 N.E.2d 775 (1983).

111. See Brookhart v. Illinois State Bd. of Educ., 697 F.2d 179, 187-88 (7th Cir. 1983) (constitutionally inadequate notice); Board of Educ. v. Ambach, 107 Misc. 2d 830, 844-45, 436 N.Y.S.2d 564, 574-75, modified, 90 A.D.2d 227, 458 N.Y.S.2d 680 (1982), affd, 60 N.Y.2d 758, 457 N.E.2d 775 (1983). But $c f$. Case No. SE-55-82, 1982-83 Educ. HANdicapped L. ReP. (CRR) 504:300 (Ill. SEA 1983) (child should graduate even though IEP did not contain specific criteria for determining that he had satisfactorily completed program).

112. Alycia C., 1980-81 Educ. Handicapped L. Rep. (CRR) 502:140 (Conn. SEA 1980); In re Steven, 1980-81 Educ. Handicapped L. Rep. (CRR) 502:143 (Md. SEA 1980); B.J.M. v. Perth-Amboy Bd. of Educ., 1982-83 Educ. Handicapped L. ReP. (CRR) 504:334 (N.J. SEA 1983); In re New Trier Township High School Dist No. 203, 1982-83 Educ. HandiCaPped L. ReP. (CRR) 504:255, :257 (Ill. SEA 1982) (eligible for services in Illinois until age 21 or successful completion of secondary program); In $r e$ Windsor Cent. High School, 1980-81 Educ. Handicapped L. REP. (CRR) 502:268 (N.Y. SEA 1981); Conn. Gen. Stat. AnN. $\$ 10-76 d(b)(1)$ (West 1981) (obligation terminates at high school graduation or age 21); N.J. Rev. STAT. ANN. $\$ 18 A: 46-14$ (West Supp. 1984) (may furnish special education to any person over 20 who does not hold a high school diploma); N.Y. EDUC. LAw $\S 4402(1)$ (b) (McKinney 1981 \& Supp. 1983) (services do not continue after age 21 or receipt of high school diploma); 1979 Op. Att'y Gen. 126 (S.C.) (neither EAHCA nor South Carolina law requires a local school district to provide a FAPE for a handicapped child who has graduated from high school or completed the program provided in his IEP). 
reaches a specified age. ${ }^{113}$ Other states declare that their obligation to provide special education services terminates when the child completes the program set forth in his individualized education program (IEP) or reaches a designated age, whichever occurs first. ${ }^{114}$ Oklahoma has chosen simply to establish a minimum number of years of service to which an exceptional child is legally entitled, while permitting continuation up to age 21.115 In addition, there are a few state agencies that are more lenient toward the continuation of special education services after the child meets requirements for graduation or completion in individual cases where such continuation appears necessary for an appropriate and adequate education. ${ }^{116}$

\section{IV}

\section{FinANCIAL ResPonsibility}

\section{A. Compensatory Education}

In the last few years there has arisen a question whether a handicapped child is ever entitled to educational services beyond age 21.117 A small number of cases have held that a school district may be required to provide compensatory educational services when it has deprived a handicapped child of a free appropriate public education because of violations of procedural safeguards and/or because of an inappropriate placement. 118 These cases, however, have arisen primarily under the federal act and have not relied upon

113. See supra note 112.

114. See In re Lincoln Consol. Schools, 1982-83 Educ. HandiCapped L. ReP. (CRR) 504:232, :234 (Mich. SEA 1982); Cal. Educ. Code $\$ 56001$ (a) (West Supp. 1984) (until completion of child's prescribed course or child meets proficiency standards); Op. Att'y Gen. No. I 79-265 (Ariz. 1979) (must provide special education until child meets IEP objectives or is 22 years old).

115. In re Broken Arrow Pub. Schools, 1982-83 Educ. Handicapped L. ReP. (CRR) 504:208 (Okla. SEA 1982); OkLa. STAT. AnN. tit. 70, § 13-102 (1972).

116. See, e.g., Wayne S. v. Framingham Pub. Schools, 1980-81 Educ. Handicapped L. Rep. (CRR) 502:238, :239 (Mass. SEA 1981) (eligibility age extended to 22 to improve reading ability); Geraldine M. v. Ashland Pub. Schools, 1979-80 Educ. Handicapped L. Rep. (CRR) 501:265, :268 (Mass. SEA 1979); In re Michigan School for the Deaf, 1982-83 Educ. Handicapped L. ReP. (CRR) 504:143 (Mich. SEA 1982) (student lacking minimum competency skills after meeting graduation requirements); see also In re J.R., 1981-82 EDUC. HANDICAPPED L. REP. (CRR) 503:291 (Nev. SEA 1981) (since district provides education to nonhandicapped students over age 18 in certain circumstances to meet graduation or completion requirements, it must do the same for handicapped students).

117. The question arises because the federal mandate in the EAHCA requires provision of special educational services through age 18 and permits an extension to age 21 if consistent with state law. 20 U.S.C. $\$ 1412(2)$ (B) (1982).

118. Campbell v. Talladega County Bd. of Educ., 1980-81 Educ. Handicapped L. ReP. (CRR) 552:472, :478 (N.D. Ala. 1981); In re Davis County Community School Dist., 1981-82 Educ. HandiCAPped L. ReP. (CRR) 503:273 (lowa SEA 1981); In re New Bedford Pub. Schools, 1982-83 Educ. Handicapped L. ReP. (CRR) 504:122 (Mass. SEA 1982) (setting forth eligibility criteria to establish prima facie case for compensatory education); Lane v. Arnold Pub. School Dist. \#89, 1980-81 Educ. Handicapped L. ReP. (CRR) 502:366, :368 (Neb. SEA 1981). Contra Adams Cent. School Dist. v. Deist, 214 Neb. 307, 334 N.W.2d 775 (1983) (state not obligated under either EAHCA or state law to provide a free appropriate public education beyond child's 21 st birthday); In re City of Yonkers, 1979-80 Educ. HaNdicapped L. REP. (CRR) 501:241 (N.Y. SEA 1979) (there is no statutory or regulatory provision in state or federal law entitling petitioner to compensatory special education services). All cases cited infra notes 120-30, were decided primarily under federal law. 
any interpretation of state law or obligations. ${ }^{119}$

A recent line of cases in the federal courts suggests that the remedy of compensatory educational services may soon become obsolete. In Anderson $v$. Thompson, ${ }^{120}$ the Court of Appeals for the Seventh Circuit held that monetary damages may be allowed under the EAHCA only in the following exceptional circumstances: (1) when a parent secures services which should have been provided by the school district to protect the physical health of the child; and (2) when the school district acts in bad faith by failing in an egregious fashion to comply with procedural provisions of the EAHCA. ${ }^{121}$ While no claim for compensatory education was made in Anderson, the court denied an award of money damages necessary to recompense the parents for cost of a unilateral placement. ${ }^{122}$ The Eighth Circuit also has held that relief under the EAHCA is usually restricted to injunctive relief and that money damages are appropriate, if at all, only under the most exceptional circumstances. ${ }^{123}$

In Timms $v$. Metropolitan School District, ${ }^{124}$ the court cited Anderson in holding that compensatory education is not recoverable under the EAHCA where school officials have made good faith, though incorrect, placement decisions, since such relief would be punitive. The court also held that the EAHCA provides the exclusive basis through which procedural noncompliance with the Act may be challenged; claims under section 504 of the Rehabilitation Act ${ }^{125}$ and under the Civil Rights Act of $1871^{126}$ would not be heard. ${ }^{127}$

In $\operatorname{Max} M$. v. Thompson, ${ }^{128}$ remedial education was denied even though the school district had failed to provide psychotherapy services recommended in its own evaluation of the child. The plaintiffs in this case alleged violations of the Illinois School Code, as well as of the EAHCA. The court found that the school code was merely a "reflection of the EAHCA on the state level" and could confer no greater rights than the federal act itself. ${ }^{129}$ The remedy of compensatory education was unavailable against either the state or the intermediate and local school defendants since monetary relief is limited to reimbursement. ${ }^{130}$ Consequently, compensatory education apparently is not an appropriate remedy for violations of a handicapped child's procedural (and therefore substantive) rights unless the state creates such a remedy by statute.

119. But see MD. Educ. Code Ann. $\$ 8.101 .1$ (Supp. 1983). This provision of the Maryland Code prescribes up to 2 years of compensatory special education services for handicapped individuals who were deprived of appropriate educational services due to health reasons or to state or local school system violations. The programs under this section were to terminate in 1983 .

120. 658 F.2d 1205 (7th Cir. 1981).

121. Id. at 1214 .

122. Id.

123. Miener v. Missouri, 673 F.2d 969 (8th Cir.), cert. denied, 459 U.S. 909 (1982)

124. 718 F.2d 212, 216 (7th Cir.), affd as modified, 722 F.2d 1310 (7th Cir. 1983).

125. 29 U.S.C. $\$ 794$ (1982).

126. 42 U.S.C. $\$ 1983$ (1982).

127. 718 F.2d at 216.

128. 566 F. Supp. 1330 (N.D. Ill. 1983)

129. Id. at 1338 .

130. Id. at 1336-37 (citing Anderson v. Thompson, 658 F.2d 1205 (7th Cir. 1981) and Miener v. Missouri, 673 F.2d 969 (8th Cir.), cert. denied, 459 U.S. 909 (1982)). 
Compensatory education is almost certainly barred as a remedy against state defendants because compensatory educational services are, like money damages, retrospective in nature; they are intended to remedy a past deprivation of educational services. Thus, as with money damages, the eleventh amendment bars an award of compensatory education against state defendants. ${ }^{131}$

\section{B. Parental and Third Party Contributions}

The EAHCA defines a free appropriate public education as "special education and related services which (A) have been provided at public expense, under public supervision and direction, and without charge. . . ."132 Accordingly, many states guarantee a special education free of charge. Nonetheless, a few states have attempted to impose some costs on the parent or guardian of the handicapped child. Such attempts have resulted in litigation over whose responsibility it is to provide or to fund various related services. ${ }^{133}$ The courts have held consistently that neither school districts nor states may charge a handicapped child or his responsible relatives for education-related services, ${ }^{134}$ though the parents or guardians may be required to assume such costs and expenses for a handicapped child as they would be obliged to pay if the child were not handicapped. ${ }^{135}$

A few states have attempted to charge parents indirectly by requiring the application of family insurance or other third party payors' obligations towards related services. ${ }^{136}$ The courts have given mixed reviews to this approach. One case arose when the New York Commissioner of Education decided that the parents of an exceptional child could be required to apply voluntarily acquired insurance benefits to the cost of providing physical and occupational therapy for their child. ${ }^{137}$ The parents petitioned the Office for Civil Rights for Region II (which includes New York) which declared that such a requirement violated section 504 of the Rehabilitation Act because payment for a portion of a public education was being sought solely from the

131. Miener v. Missouri, 673 F.2d 969, 982 (8th Cir.), cert. denied, 459 U.S. 909 (1982).

132. 20 U.S.C. $\S 1401(18)$ (1982).

133. See supra notes 51-63 and accompanying text.

134. See, e.g., Parks v. Pavkovic, 557 F. Supp. 1280 (N.D. Ill. 1983).

135. 34 C.F.R. $\S 300.14$ (b)(1) (1984). See also N.D. Cent. Code $§ 15-59-02.1$ (1981).

136. See Cal. Educ. Code $\$ 56363.5$ (West Supp. 1984) (school district may seek reimbursement from insurance companies either directly or through the pupil's parents); MASs. ANN. LAws ch. $71 \mathrm{~B}, \S 5$ (Law. Co-op. Supp. 1983) (school committee is not required to pay for medically necessary treatment which would be covered by a third party payor but for child's eligibility for goods and services under this chapter); ILl. ANN. STAT. ch. 122, § 14-7.02 (Smith-Hurd Supp. 1983) (State's liability for funding of these tuition costs never to begin until after the legal obligations of third party payors have been subtracted from such costs); N.D. CENT. CoDE $\$ 15-59-02.1$ (1981) (requiring use of insurance or third party payments when determining school district's responsibility for providing special education resulting from a child's medically related handicapping condition). Each of these statutes provides that the school district must assume costs not covered by such payments.

137. In re Three Village Cent. School Dist., 1979-80 Educ. Handicapped L. ReP. (CRR) 501:320 (N.Y. SEA 1979). 
parents of handicapped pupils. ${ }^{138}$ The New York Commissioner of Education then annulled his first decision and followed the pronouncement of the Office of Civil Rights. ${ }^{139}$ While following the law of his region, the Commissioner's second ruling observed that the Office of Civil Rights for Region V had found that the State of Illinois could compel the use of insurance benefits to cover educational expenses. ${ }^{140}$

Given the current split among jurisdictions, one can probably anticipate further litigation in this area. In some respects, the EAHCA does seem to allow the requirement of third party contributions. Its policy of leaving primary control of substantive matters and the bulk of funding in the hands of the state and local school districts indicates an intent to give the states free rein over such matters. ${ }^{141}$ Moreover, a federal regulation regarding methods of payment for a free appropriate public education states that "[n]othing in this part relieves an insurer or similar third party from an otherwise valid obligation to provide or pay for services provided to a handicapped child." 142 In addition, the Department of Education issued an interpretation of Part B of the EAHCA and section 504 of the Rehabilitation Act $^{143}$ in December, 1980. The Department stated:

Both Part B and Section 504 prohibit a public agency from requiring parents, where they would incur a financial cost, to use insurance proceeds to pay for services that must be provided to a handicapped child under the "free appropriate public education" requirements of these statutes. The use of parents' insurance proceeds to pay for services in these circumstances must be voluntary on the part of the parents. ${ }^{44}$

Thus, parents may be asked to apply insurance benefits to their handicapped child's education if they will suffer no financial loss by filing a claim. ${ }^{145}$

On the other hand, insofar as the parents have paid the insurance premiums and insofar as both their ability to obtain insurance in the future and their insurance rates are affected by the required use of such benefits to pay for education-related services, these handicapped children are not receiving services without charge. In addition, such a requirement may discriminate unlawfully between the parents of handicapped and nonhandicapped chil-

138. See In re Three Village Cent. School Dist., 1980-81 Educ. Handicapped L. ReP. (CRR) 502:141,:142 (N.Y. SEA 1980).

139. Id.

140. Id.; Illinois Bd. of Educ., 2 [EHA Decisions] Educ. HandicapPed L. ReP. (CRR) 257:82 (Ill OCR 1980). But see School Dist. \#220, 2 [EHA Decisions] Educ. Handicapped L. ReP. (CRR) $257: 200$, :202 (Ill. OCR 1981) (parents may no longer be required to use private insurance to pay for residential programs, including nonmedical care and room and board). See also comments on the Illinois statute in Kula, The Right to Special Education in Illinois - Something Old and Something New, 55 Chi.-Kent L. Rev. 649, 679-81 (1979).

141. See 20 U.S.C. $\$ \S 1400-1461$ (1982).

142. 34 C.F.R. $\$ 300.301$ (b) (1984).

143. 29 U.S.C. $\$ 794$ (1982).

144. 45 Fed. Reg. 86,390 (1980) (emphasis added).

145. The Department's interpretation states that financial losses include, but are not limited to: “(1) A decrease in available lifetime coverage or any other benefit under an insurance policy; (2) An increase in the premiums or the discontinuation of the policy; or (3) An out-of-pocket expense such as the payment of a deductible amount incurred in filing a claim." 45 Fed. Reg. 86,390 (1980). "Financial losses do not include incidental costs such as the time needed to file an insurance claim or the postage needed to mail the claim." Id. 
dren, or between the parents of handicapped children who do and those who do not have insurance benefits that will cover these expenses. ${ }^{146}$

\section{Conclusion}

While statutory language as well as case law regarding handicapped education is not totally consistent among the states, this investigation of the various state responses to the EAHCA revealed very few, if any, remarkable contrasts or differences among jurisdictions. Obviously no state can provide all things to all people, whether handicapped or not. Some educational requests are clearly outside of what any jurisdiction has undertaken an obligation to meet, and are consequently likely to be denied in almost every case. Conversely, the failure to provide for other more basic needs would be tantamount to totally ignoring the EAHCA, and no state has so failed.

Cases in the gray areas are the ones that ought to provide an indication of any appreciable variations among states. Although the "hard" cases exist, no distinguishing trends appear. The reasons for this relate to the very nature of the problem. Because the EAHCA so pervades the legislative background and case law of the states, it is difficult to separate decisions based on state law from those based either solely on federal law or on a combination of state and federal law. In addition, each child has unique problems and potential, so that no case is truly on "all fours" with any other. Therefore, comparing and distinguishing cases in the special education area is less instructive than such analysis in other more doctrinal areas of the law. Moreover, statutory terms such as "appropriate education" are by their very nature vague. As a result, agencies and courts are applying vague standards to highly fact-dependent cases. Apparent consistency is a victim of such circumstances.

The fact that the "hard" cases are not totally consistent from state to state, or even within states, ought not give rise to concern, given the structure of the EAHCA. Indeed, uniformity in the clear cases along with fluctuations at the borderlines is to be expected in a system which provides federal funding to help meet the national goal of providing a free appropriate education to all handicapped children, while leaving implementation decisions with those state and local authorities which have traditionally been responsible for education.

146. See In re Three Village Cent. School Dist., 1980-81 Educ. Handicapped L. Rep. (CRR) 502:141 (N.Y. SEA 1980); 45 Fed. Reg. 86,390 (1980) (will not require parents to contribute insurance benefits where they would suffer a financial loss not incurred by similarly situated parents of nonhandicapped parents). 